\title{
Pollination and floral biology of Adonis vernalis L. (Ranunculaceae) - a case study of threatened species
}

\author{
Bożena Denisow ${ }^{1}$, Małgorzata Wrzesień2 ${ }^{2}$ Anna Cwener ${ }^{2 *}$ \\ 1 Department of Botany, University of Life Sciences in Lublin, Akademicka 15, 20-950 Lublin, Poland \\ ${ }^{2}$ Institute of Biology and Biochemistry, Maria Curie-Skłodowska University, Akademicka 19, 20-033 Lublin, Poland
}

\begin{abstract}
Although the knowledge of pollination systems of rare and threatened species is one of the principles for development of optimal conservation and management strategies, the data about their pollination requirements are scarce or incomplete. Different problems are listed (xerothermic habitat disappearance, overgrowing of patches, plant biology i.e., slow plant growth, problems with seed germination) among the possible causes of Adonis vernalis being threatened, but until now no consideration was given to the flowering biology and pollination.

The observations of flowering biology of A. vernalis (Ranunculaceae), a clonal species, were conducted in an out-ofcompact-range population, in the Lublin Upland, Poland $\left(51^{\circ} 18^{\prime} 55^{\prime \prime} \mathrm{N}, 22^{\circ} 38^{\prime} 21^{\prime \prime} \mathrm{E}\right)$, in $2011-2013$. The reproductive potential of $A$. vernalis is related to the population age structure, pollination syndrome, and breeding system. The flowers exhibit incomplete protogyny. The dichogamy function is supported by different (biological, morphological) mechanisms. Stigma receptivity occurred about one day before anthers started shedding self-pollen, and pollen viability was increasing gradually during the flower life-span (66.3\% in distal anthers vs. $77.3 \%$ in proximal). The decrease in pollen production and in pollen viability coincided with the lowest degree of seed set, irrespective of the pollination treatment. Pollen vectors are necessary for efficient pollination, as the proportion of pistils setting fruits after open pollination (41-82.1\%) was significantly higher compared to spontaneous self-pollination (only 5.5-12.3\%). The pollination requirements together with pollen/ovule ratio $(\mathrm{P} / \mathrm{O}=501)$ indicate a facultative xenogamous breeding system in $A$. vernalis. Therefore, in the conditions of the global lack of pollinators, improper pollination may weaken the population by leading to a decrease in the proportion of recombinants, and in addition to other factors, may accelerate extinction of small A. vernalis populations.
\end{abstract}

Keywords: Adonis vernalis; self-pollination; open-pollination; pollen; viability; seed set

\section{Introduction}

Conservation of biodiversity refers to different levels of ecological organization (species, biocenoses, ecosystems). In conservation efforts, special interest is devoted to the protection of rare and endangered species, many of which may impact the stability of pollination webs, although mutualistic relations are highly asymmetrical $[1,2]$. The first step to protect various ecological interactions between organisms is to understand the particular species biology and ecology. Surprisingly, our knowledge of species properties, especially of pollination requirements is still incomplete, even in well-researched floras [3]. Meanwhile, the information on the plant-pollinator relationship and plant requirements for the gene flow is particularly important for proper maintenance of "healthy" populations of rare and endangered

\footnotetext{
* Corresponding author. Email: acwener@wp.pl
}

Handling Editor: Łukasz Łuczaj species within the metapopulation system [4]. In Poland, detailed studies on pollination systems and reproductive strategies are available for less than $20 \%$ of the endangered species, but in recent years, attempts have been made to fulfil the gap [5]. One of the species with the conservation priorities at the national and internationals levels is Adonis vernalis L. (Ranunculaceae), a species characteristic for xerothermic grasslands of the continental-submediterranean type, belonging to the Festucetalia valesiaceae order [6]. Most populations of $A$. vernalis have declined in size considerably in many European countries in recent decades [7-12], and therefore, as a threatened species, it is maintained under the CITES agreement.

In Poland, the populations of $A$. vernalis are located out of the compact range [13] and the causes of the species being threatened are complex. They include overexploitation of populations (gathering for medical purposes), habitat disappearance (i.e. intensive agricultural practices) [14-16] or overgrowing of patches due to secondary succession of grasslands $[17,18]$. Some causes are within the biology and 
ecology of the plant, i.e., slow growth, or problems with seed germination [19].

In the case of clonal species, including A. vernalis, vegetative reproduction seems to be a crucial strategy for maintenance of individuals in the community [20-22]. However, generative propagation is essential from the genetic and evolutionary perspective. It contributes to improvement of the genetic variability of individuals (outcrossing) within the population and between different populations [23].

Adonis vernalis produces protogynous flowers, in which maturation of anthers and stigmas occurs at different times; receptive stigmas are presented before anther dehiscence [24]. Dichogamy was evolved to reduce interference between pollen import and export, and the effective pollination period is closely linked with the duration of stigmatic receptivity and pollen accessibility $[25,26]$. A high level of outcrossing is expected in dichogamous flowers. In protogynous $\mathrm{Ra}-$ nunculaceae, a high degree of self-fertility is possible, which suggests that protogyny is to some extent incomplete $[27,28]$.

Pollen characteristics, i.e. pollen viability, pollen germination, or pollen-tube survival are essential in the process of generative reproduction [29-31]. The quantity and quality of $A$. vernalis pollen may differ greatly between populations [9,32]. Fruiting and seed set is dependent on fertilization, which is the result of pollination; therefore, failure of pollination may be fundamental for reproduction of entomophilous species [30].

Since no knowledge of pollination biology is available, it seems reasonable to fulfill the gap for $A$. vernalis. The specific aims of the study were $(i)$ to describe the details of flower biology, especially the time of stigma receptivity and anther dehiscence, $(i i)$ to find out whether pollen characteristics may have an impact on the reproductive success and (iii) to determine to what degree insect visitors influence the seed set.

\section{Material and methods}

\section{Study site}

The observations were conducted in 2011-2013 in a population of the species in the Lublin Upland at Pliszczyn site $\left(51^{\circ} 18^{\prime} 55^{\prime \prime} \mathrm{N}, 22^{\circ} 38^{\prime} 21^{\prime \prime} \mathrm{E}\right)$, Poland. Adonis vernalis was a component of the Adonido-Brachypodietum pinnati association (Libb. 1933) Krausch 1960 of the Festuco-Brometea Br.-Bl. et R. Tx. 1943 class [33]. The population was situated on a loess-covered slope of the river Bystrzyca valley with south inclination. The $A$. vernalis population was estimated at ca. 300 individuals. The xerothermic patch was dominated by grass and meadow species [Medicago falcata L., Brachypodium pinnatum (L.) P. Beauv., Galium verum L. s.str., Euphorbia cyparissias L., Veronnica spicata L., Salvia pratensis L., Phleum phleoides (L.) H. Karst., Chamaecytisus ratisbonensis (Schaeff.) Rothm.].

\section{Study species}

Adonis vernalis (Ranunculaceae) is a herbaceous early spring perennial, characterized by clonal, clump growth. A single clump consists of 1-several modules that may consist of 1-5 different individuals (ramets). Modules are distinguished, since there are some difficulties in determination of plant individuals and separation thereof from the clump. Development of clumps involves several phases, during which the number of virginile and juvenile individuals in clumps increases with an increase in the clump area and the number of flower shoots developing from one bud increases with the clump age. The flowering of an individual plant does not occur before the third or fourth year of its life history [34,35].

The bisexual flowers of $A$. vernalis have typical entomophilous features. The flowers are cup-shaped, actinomorphic, and bright-colored. The gynoecium consists of many 1-ovuled carpels. Flowers produce pollen as floral reward and due to the early blooming period may be valuable for bee-like hymenoptera [32]. The flowers are considered to be protogynous [36]. Fructification is reported to be highly changeable among separate clumps, populations, and growing seasons $[35,37]$.

\section{Study methods}

During the full flowering phase in the population, the clumps $(n=40)$ were randomly chosen and marked in order to establish the proportion of vegetative and generative shoots. The clump was defined according to JankowskaBłaszczuk [35] as a spatially distinguishing group of modules (i.e. a specially distinguishing group of shoots) that may consists of a different number of individuals (i.e. ramets). Two weeks after the end of flowering, all fruiting shoots were counted and the proportion of fruiting shoots to the total flowering shoots was calculated.

\section{Flower development}

To determine the temporal separation of stigma receptivity and anther dehiscence, the flower development was monitored in 12-20 randomly chosen flowers, from the bud stage until the end of pollen presentation. Every day we recorded the degree to which stigmas were exerted, and the number of dehiscing anthers. Based on this observation, floral stages (1-7) were distinguished. The number of anthers per flower ( $n=12-28$ flowers) and the number of pistils per flower ( $n=12-28$ flowers) were established.

\section{Stigma receptivity}

Timing of stigma receptivity was determined at each of the seven stages of floral development. 30\% hydrogen peroxide was applied for detection of peroxidase activity (SPA) [38]. The entire gynoecium from flowers was placed on a glass slide and coated in a drop of $\mathrm{H}_{2} \mathrm{O}_{2}$. Stigmas that produced bubbles within 2-3 min were considered receptive. The number of receptive stigmas was counted for each individual flower under a binocular (NIKON SMZ-2B). The observations were made in laboratory conditions on plants transferred from the study site and grown in pots in an unheated, ventilated experimental greenhouse (day and night air temperature analogous to the outdoor conditions). After the experiment, the plants were removed to the natural patch.

\section{Pollen quantity and quality}

The anther size (determined as a dry weight of 100 anthers) and the mass of pollen in the anthers were determined 
Tab. 1 The percentage proportion of vegetative and generative shoots per clump of Adonis vernalis and the flower longevity with duration of stigma and pollen presentation in flowers in the years 2011-2013.

\begin{tabular}{|c|c|c|c|c|c|c|}
\hline \multirow[b]{2}{*}{ Year } & \multicolumn{3}{|c|}{ Proportion of shoots (\%) } & \multicolumn{3}{|c|}{ Duration of (days) } \\
\hline & vegetative & flowering & fruiting & flower life-span & stigma receptivity & pollen presentation \\
\hline 2011 & $42.6^{\mathrm{a}} \pm 12.3$ & $47.4^{\mathrm{a}} \pm 7.8$ & $28.5^{\mathrm{a}} \pm 7.3$ & $12.2^{\mathrm{b}} \pm 3.1$ & $8.3^{\mathrm{b}} \pm 2.1$ & $10.0^{\mathrm{b}} \pm 2.4$ \\
\hline 2012 & $54.6^{\mathrm{a}} \pm 7.7$ & $45.4^{\mathrm{a}} \pm 32.5$ & $30.6^{\mathrm{a}} \pm 12.1$ & $11.5^{b} \pm 2.6$ & $8.1^{b} \pm 1.6$ & $9.4^{\mathrm{b}} \pm 2.1$ \\
\hline 2013 & $59.1^{\mathrm{a}} \pm 21.6$ & $40.9^{\mathrm{a}} \pm 17.8$ & $39.4^{\mathrm{a}} \pm 9.3$ & $7.3^{\mathrm{a}} \pm 4.1$ & $4.7^{\mathrm{a}} \pm 1.6$ & $5.6^{\mathrm{a}} \pm 1.1$ \\
\hline Mean & $52.1 \pm 19.2$ & $44.6 \pm 12.5$ & $32.8 \pm 6.7$ & $10.3 \pm 2.8$ & $7.5 \pm 2.5$ & $8.4 \pm 3.9$ \\
\hline
\end{tabular}

Means in columns with the same letters are not significantly different at $P=0.05$, for vegetative, generative and fruiting shoots according to Kruskal-Wallis test, and for floral traits according to HSD Tukey test. Means are presented as mean $\pm S D$.

in proximal, middle, and distal anthers. Fully-grown and unopened anthers were randomly collected from appropriate parts of the androecium before anther dehiscence. The anthers were separated from filaments and placed in weighed glass containers. Four replications with $n=100$ anthers for each position was prepared for analyses. The glass containers were placed in a dryer (ELCON CL 65) at ca. $33^{\circ} \mathrm{C}$ for 3-5 days and weighed. Then the pollen was rinsed from the anthers once with pure ether (1-2 ml) and then 4-6 times with $70 \%$ ethanol $(2-8 \mathrm{ml})$. The accuracy of the pollen rinsing was checked using a binocular.

To calculate pollen-ovule ratio (P/O) [39], the number of pollen grains per anther $(n=10)$ and the number of ovules in the flower were counted and the pollen/ovules ratio was estimated ( $n=12-15$ flowers).

The value of pollen was evaluated by its viability in a standard $2 \%$ acetocarmine solution and observed on microscopic slides. Pollen from proximal, middle, and distal anthers ( $n=300$ pollen grains from each position) was studied. A Nikon Eclipse E 200 light microscope was used.

\section{Pollination requirements}

The apocarpous gynoecium has multiple distinct carpels, each of which contains a single ovule and developed singleseeded achenes, and does not split open when ripe [40]. The degree of pollination was established as the proportion of fruits (i.e. seeds) set in relation to the number of pistils. The number of pistils and seeds was detected separately in each flower; 15-22 flowers were used for each pollination treatment. Two treatments were designed to investigate pollination ecology:

(i) spontaneous self-pollination - the experimental flowers from the bud stage were bagged with isolators (mesh size $<1 \mathrm{~mm}$ ) to prevent insect visitations;

(ii) open-pollination - natural conditions; the flowers were exposed to pollinator visits.

Insect visitors were observed during the time of the full bloom phase of the population by walking of 2-3 persons, through the population in an area of ca. $200 \mathrm{~m}^{2}(4 \times 50 \mathrm{~m}$ transects). The total sampling time was roughly 40 hours (all observers and years combined).

\section{Data analysis}

Data are presented as means with standard deviation $(S D)$. Whenever possible, parametric statistical analysis was applied [41]. One-way ANOVA was used to test the effect of year on the number of anthers per flower, the dry mass of anthers, the mass of pollen in anthers, pollen viability, and for effect of the pollination treatment (open-pollination vs. spontaneous self-pollination) on the seed set. Post hoc comparison of means was tested by the HSD Tukey test. The time for stigma receptivity vs. pollen presentation was compared using the independent samples $t$-test. The Kruskal-Wallis test was used to determine the differences for non-normally distributed data (the proportion of vegetative, generative, and fruiting shoots among years). The Pearson correlation coefficient was used to test relationship between the seed set and the mass of pollen produced in flowers, and between the seed set and pollen viability. The level of statistical significance for all analyses was at $\alpha=0.05$. All analyses were performed using Statistica ver. 9.0 (StatSoft Poland, Cracow).

\section{Results}

\section{Flowering and fructification}

The number of flowers produced per plant varied depending on the number of modules evolved per plant and was changeable among the growing seasons. The number of generative shoots was the lowest for a 1-module clump (mean $=6.6 \pm 4.1 S D$ ), and the most abundant flowering was characteristic for a 4-module clump (mean $=17.3 \pm 2.1 S D)$. The proportion of the collective fruit set was $26.4-38.2 \%$ in relation to flowering shoots. Consequently, the highest number of fruiting shoots was found for 3-4 module clusters. No year effect was found for both the number of generative shoots (Kruskal-Wallis test: $H=1.69, d f=2, P=0.428)$ and the number of vegetative shoots $(H=2.21, d f=2, P=0.331)$. The highest proportion of collective fruits developed was noted in 2013, and the value was $22-30 \%$ higher compared to that obtained in the years 2011-2012, but the difference was not statistically significant $(H=0.24, d f=2, P=0.884$; Tab. 1). 


\section{Flower stages}

The Adonis vernalis flower life-span, from corolla opening till wilting, was 10.3 days $\pm 2.8 S D$, on average. In 2011 and 2012, the flower life-span averaged 12.2 and 11.5 days, respectively, and was longer than in 2013 (mean $=7.3$ days, $\left.F_{2.28}=29.37, P=0.024\right)$. The flower development allows distinguishing 7 relatively distinct stages (Fig. 1). Stage 1 - tight yellowish bud, no stigma receptivity and no pollen release; stage 2 - loose bud and beginning of stigma receptivity; stage 3 - corolla opened, elongation of styles and receptivity of stigmas in lower pistils; stages $4-5$ with increasing receptivity of stigmas in $>30 \%$ of pistils, dehiscence of first anthers; stage 6 - a systematic decrease in the number of receptive stigmas, pollen release and fruit development; stage 7 - no stigma receptivity was noted, pollen presentation disappeared, while the number of set fruits systematically increased. The flowers spent a similar time in stigma (mean $=7.5 \pm 2.6 S D)$ and pollen presentation (mean $=8.4 \pm 2.6 S D ; t=8.9, P>0.05$ ).

\section{Androecium and gynoecium characteristics}

The anthers of Adonis vernalis are spirally arranged at the flower bottom; their ripening was gradual and pollen shedding started from the distally positioned anthers. The apocarpous gynoecium consists of many simple carpels, ranging from 32 to 86 per single flower $($ mean $=51.3 \pm 16.2 S D)$. The number of anthers per flower varied significantly from yearto-year $\left(F_{2.11}=19.37, P=0.034\right.$; Tab. 2$)$. The mean number of anthers per flower was $120.2 \pm 48.2 S D$; the mean number of pollen grains per anther was $214.3 \pm 201.6 S D$; and the calculated pollen/ovule (P/O) ratio amounted to 501 .

In general, the year effect was established for the dry mass of anthers $\left(F_{2.61}=11.6, P=0.041\right)$, the mass of pollen produced in anthers $\left(F_{2.11}=24.42, P=0.022\right)$, the mass of pollen per flower $\left(F_{2.11}=3.76, P=0.021\right)$, and pollen viability
Tab. 2 The characteristic of androecium, the dry mass of anthers, the mass of produced pollen and the pollen viability in Adonis vernalis in 2011-2013.

\begin{tabular}{lcccc} 
Year & $\begin{array}{c}\text { Number of } \\
\text { anthers per } \\
\text { flower }\end{array}$ & $\begin{array}{c}\text { Dry mass of } \\
\mathbf{1 0 0} \text { anthers } \\
(\mathbf{m g})\end{array}$ & $\begin{array}{c}\text { Mass of } \\
\text { pollen per 100 } \\
\text { anthers }(\mathbf{m g})\end{array}$ & $\begin{array}{c}\text { Viability } \\
(\mathbf{\%})\end{array}$ \\
\hline 2011 & $131.3^{\mathrm{c}} \pm 31.2$ & $9.2^{\mathrm{b}} \pm 2.6$ & $2.8^{\mathrm{b}} \pm 2.1$ & $83.5^{\mathrm{b}} \pm 7.4$ \\
2012 & $105.7^{\mathrm{a}} \pm 28.6$ & $5.7^{\mathrm{a}} \pm 1.9$ & $1.1^{\mathrm{a}} \pm 1.6$ & $36.1^{\mathrm{a}} \pm 3.9$ \\
2013 & $123.4^{\mathrm{b}} \pm 17.3$ & $6.9^{\mathrm{a}} \pm 2.8$ & $2.3^{\mathrm{b}} \pm 1.5$ & $95.4^{\mathrm{c}} \pm 4.0$ \\
Mean & $120.1 \pm 2.1$ & $6.3 \pm 3.6$ & $2.1 \pm 2.9$ & $71.7 \pm 12.3$ \\
\hline
\end{tabular}

Means in columns with the same letters are not significantly different at $P=0.05$ (HSD Tukey test). Means are presented as mean $\pm S D$.

$\left(F_{2.11}=27.60, P=0.016\right)$. For example, the mass of produced pollen was similar in 2011 and 2013, and decreased in 2012 by $60 \%$ and $52 \%$, respectively.

The mass of pollen produced in anthers $\left(F_{2.24}=3.28\right.$, $P=0.047)$ and the pollen viability $\left(F_{2.24}=5.38, P=0.032\right)$ were related to the position of stamens in the androecium (Fig. 2a,b). In general, the pollen mass was the lowest in the distally positioned anthers (mean $=1.4 \mathrm{mg} \pm 0.7 \mathrm{SD}$ ), and was lower by $44 \%$ and $36 \%$ compared to the mass of pollen produced in the mid and proximal anthers, respectively. Also the lowest pollen viability was noted in the distal anthers (mean $=66.3 \% \pm 26.1 S D$ ), and the value increased gradually reaching $71.6 \% \pm 27.6 S D$ in the mid-positioned anthers, and viability reached $77.3 \% \pm 27.7 S D$ in the proximal anthers.

There was a positive correlation between the seed set and the mass of pollen produced in flowers (Pearson correlation

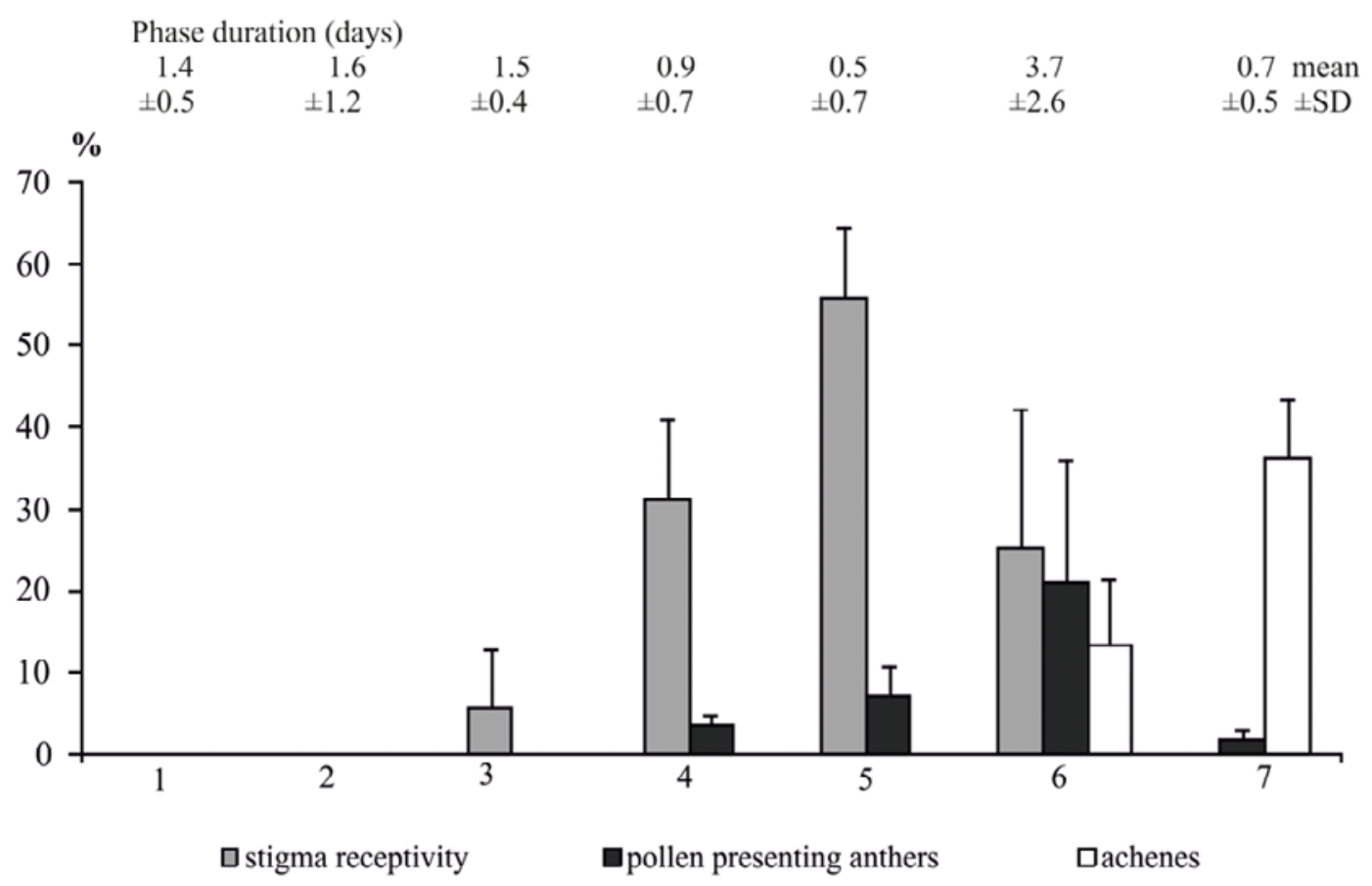

Fig. 1 The duration of floral phases (1 - greenish bud, 2 - loose bud, 3-7 corolla opened) and the proportion of receptive stigmas in gynoecium, the proportion of pollen presenting anthers in androecium and the proportion of achenes per flower of Adonis vernalis in consecutive stages of flower development. Means are calculated from 2011-2013. SD are given - vertical bars. 

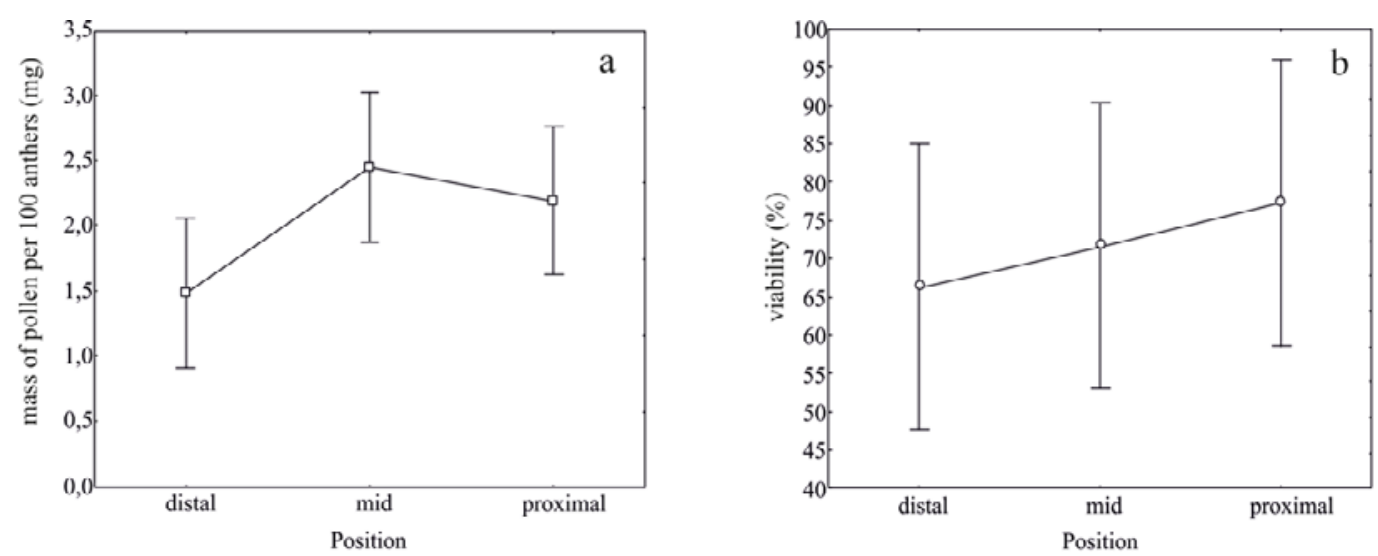

Fig. 2 The effect of the stamens position in the androecium on the mass of pollen in anthers (a), and the pollen viability in Adonis vernalis (b; means calculated from 2011-2013). Vertical bars show 95\% confidence intervals.

$r=0.708, P<0.05)$, and between the seed set and pollen viability $(r=0.630, P<0.05)$. The lowest mass of pollen produced in anthers (mean $=1.1 \mathrm{mg}$ per 100 anthers) and the lowest percentage of viable pollen grains with normal morphology $($ mean $=36.1 \%)$ were recorded in 2012, when the number of seeds developed was also the lowest (mean $=41.3 \% \pm 12.6 S D$, after open-pollination and $5.5 \%$ $\pm 2.3 S D$ after self-pollination).

\section{Insect visitors and seed set}

In the population of $A$. vernalis studied, the Chlamydatus sp. (Heteroptera) was found to be the most frequent insect flower visitor. Beetles from the genus Mordellistena (Fig. 3a), Anthonomus sp., and Cantharis sp. were also noted. Among bee-like Hymenoptera, solitary bees (81.2\%), Bombus species (9.6\%) and Apis mellifera L. (8.2\%) were recorded. Among solitary bees: Osmia rufa L., Andrena albicans Misident, Andrena cineraria L., Andrena sp., and Halictus sp. were noted, while among bumblebees: Bombus terrestris L., $B$. pascuorum Scop., B. lapidarius L., were observed. However, the visitation rate of bees was very low (1-2 insect visitors per hour per 50-m transect).
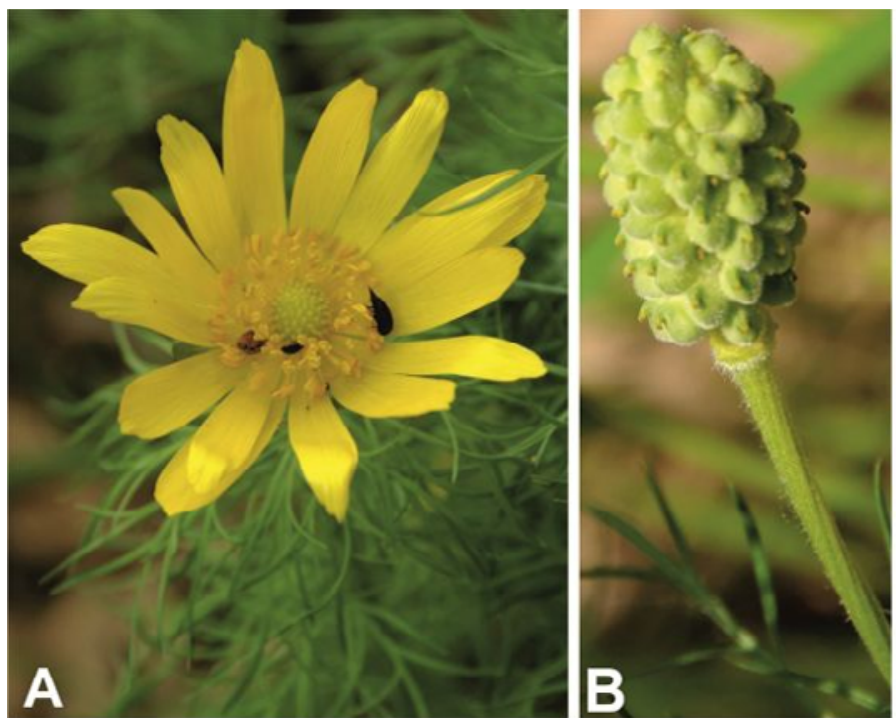

A highly significant effect of the pollination treatment (open-pollination vs. pollinator exclusion $F_{1.28}=29.37$, $P=0.004)$ and the growing season $\left(F_{2.33}=19.43, P=0.027\right)$ on the seed set was revealed for the experimental Adonis vernalis plants (Fig. 3b-d, Fig. 4). Irrespective of the study years, a 7-9 fold higher number of achenes were developed after open pollination. The seed set after spontaneous selfpollination was $5.5-12.3 \%$, and it was the highest after open pollination, i.e. $41-82.1 \%$. In the case of both pollination treatments, the lowest number of seed set was noted in 2012.

\section{Discussion}

During their life history, the clumps of $A$. vernalis undergo several phases of development. In the studied population, we observed 1-4 module clumps, similarly to two other studies $[35,37]$. The clump structure had an impact on the number of developed flowers. Although the number of developed fruiting shoots was variable among the years, the relationship between the number of fruiting shoots and the number of flowering shoots correlated positively. This observation

Fig. 3 The flower of Adonis vernalis with Mordellistena beetle (a) and the seed set after open-pollination (b,c) and after spontaneous self-pollination (d). 


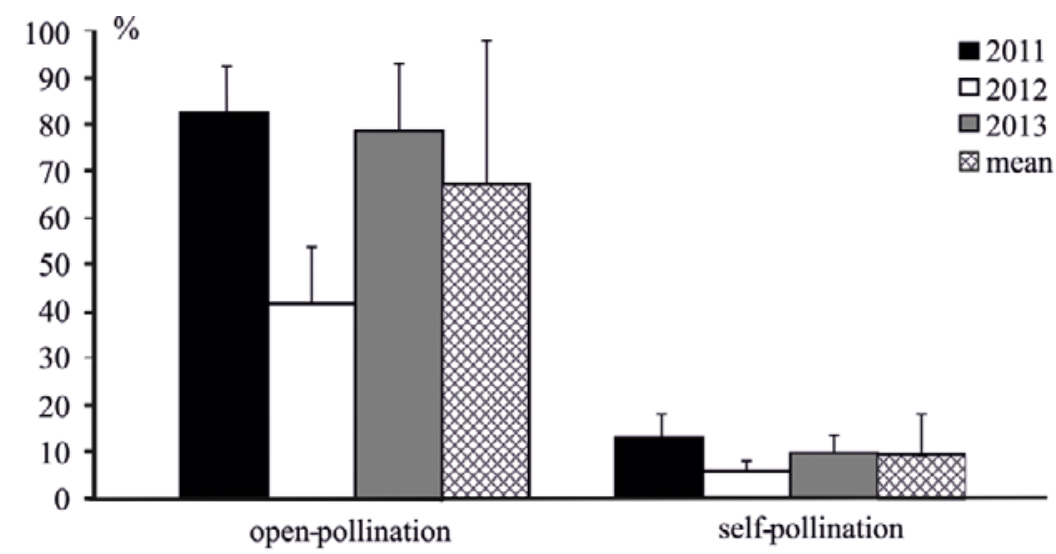

Fig. 4 The proportion of seed set in relation to pistils after open-pollination and after spontaneous self-pollination (insect visitors excluded) in Adonis vernalis in the years 2011-2013. Mean values and $S D$ (vertical bars) are given.

coincides with the conclusion of two other studies [34,35] that the population age structure influences the reproductive potential of $A$. vernalis.

To our knowledge, this is the first study to reveal the significant impact of the pollination requirements and the breeding system on the seed set in $A$. vernalis. The comparison of the proportion of pistils setting fruits (i.e. seeds) after open-pollination and spontaneous self-pollination (i.e. pollinators exclusion) treatments indicates that pollen vectors are necessary for efficient pollination. In the current study, we noted different groups of bees (Hymenoptera) as insect visitors similar to findings for other $A$. vernalis populations $[32,42]$, but their activity in flowers was very scarce (1-2 insect visitors per hour per $50 \mathrm{~m}$ transect). This coincides with the opinion presented in Chmura et al. [37] about the low frequency of entomofauna on $A$. vernalis. The low frequency of flower visitors to Adonis flowers may be related to low early spring temperatures, as air temperature during flowering was usually below $15^{\circ} \mathrm{C}$. Several studies have demonstrated that lower insect visitation is caused by temperature. In a spring ephemeral Adonis ramose Franch, Kudo [43] found that the activity of visiting insects was dependent on temperature, and cool temperatures restricted their frequency. However, bumblebees, as visitors that forage at ambient temperatures of $5^{\circ} \mathrm{C}$ or less, are reported as foragers to early spring flora of xerothermic swards in Poland [44]. Bumblebees were also noted in our study but their frequency was very low, surprisingly much lower than that of solitary bees. One of the possible causes may be the low population size and density of bumblebee individuals in the study area [45].

For the early spring flora, the low activity of flower visitors can be a decisive factor in reduction of outcrossing frequency. However, it is necessary to note that the interactions between flowers and their pollinators are complex, and many factors (not only environmental) may affect the relation. Among others, the energy budget of pollinators in relation to the food reward offered seems to play a significant role in the evolution of the plant pollination system $[36,46]$. The flowers of $A$. vernalis offer only pollen as floral reward, therefore they are of low energetic potential. Chittka et al. [47] found that nectarless species receive fewer insect visits than concurrently blooming nectar-producing species. According to the "energy balance" theory, the species that are not able to provide high caloric reward develop alternative strategies to ensure pollen transfer [46]. In the case of $A$. vernalis, the population structure and the clump architecture seems to be an important tool supporting gene flow. Flowers within the clump appear close to each other and therefore may contribute to reduction of energy spent by potential pollinators for the flights among the flowers. Compact blooming flowers can be visited in rapid succession and the pollen transfer between the flowers is more likely. Additionally, for the one-ovuled pistils, theoretically, only one pollen grain is necessary to produce a single seed; hence, there is no need for the pollinator to make repeated visits for efficient pollination.

Mating and sleeping Hemiptera (mainly Chlamydatus sp.) and Coleoptera insects were observed in the flowers, which provided evidence for combined flower function (food, shelter), thereby implying a strong impact of A.vernalis on insect biodiversity. Their function as pollen agents and pollinators cannot be excluded either. In contrast to Knuth [42], we did not observe dipterans. Several factors operating simultaneously may contribute to these discrepancies, one of which was abundant blooming of co-flowering Euphorbia cyparissias, very willingly visited by dipterans.

Other possible factors that may limit the seed set in A. vernalis are associated with internal biological parameters. We found a positive relationship between the qualitative and quantitative traits of pollen and the reproductive success of A. vernalis. The reduced pollen production together with the decrease in pollen viability coincided with the lowest degree of seed set in 2012, irrespective of the pollination treatment applied. Pollen viability is considered as fundamental for fertilization $[29,38]$. In our study, the pollen viability varied significantly among the years (36.1-95.4\%). Considerable differences of pollen viability were also noted in other A. vernalis populations (43-98.5\%) [32]. These observations indicate high dependence of microsporogenesis from external factors. The adverse effect of abiotic conditions, e.g. air temperature or drought, on pollen grain formation and reproductive success is widely accepted [29]. Temperature stress or a low precipitation level during flowering reduced 
seed yield in different species of crop plants e.g. Brassica napus L. [48], and wild species, e.g. Linum usitatissimum L. [49]. Furthermore, occurrence of the persistent tapetum is specific for $A$. vernalis. The persistent tapetum is known to be able to block nutrient transportation and initiate the process of pollen grain abortion or induce the development of microspores into unviable pollen grains [40]; therefore, this anatomical trait may cause reproductive problems in A. vernalis.

Also disorders in pollen productivity may contribute to poor seed set, as an adequate amount of pollen is necessary for complete fertilization of available ovules $[25,30]$. In our study, the lowest pollen mass produced in anthers was noted in the year of the lowest seed yield. The dependence shows that the male derivative potential of plants may be critical for reproductive function, as pointed out by [31].

The flowers of $A$. vernalis exhibit incomplete protogyny based on Lloyd and Webb's criteria [24]. Medvegy et al. [36] described $A$. vernalis as a protogynous species. In our study, the protogyny turned out to be relatively ineffective in reducing self-pollination, as seed set was noted after spontaneous autogamy (5-12\%). Among Ranunculaceae species, incomplete protogyny was also described in Aquilegia canadensis L. or Anemone canadensis L. [27,28]. Although the protogyny is incomplete, the dichogamy function is supported by different (biological, morphological) mechanisms. Stigma receptivity occurred about one day before anthers started shedding self-pollen, and pollen viability was increasing gradually during the flower life span. The changes in pollen viability to support the reproductive function are regarded as a common trait among different, mainly dichogamous, Angiosperm plants [50].

Although the reproductive efficiency after spontaneous self-pollination is rather low, in comparison to open crosspollination, and may not guarantee an adequate reproductive output for individuals, it can act as assurance for reproduction, i.e. in the condition of the lack of pollinators or while colonizing new areas. Given the extremely low pollinator visitation rates documented for $A$. vernalis [32,37], selection

\section{Acknowledgments}

We are immensely grateful to our three anonymous Reviewers for helpful comments, remarks, suggestions and for the amazing support given for the manuscript. Our thanks go also to Rafał Gosik, for the insect visitors identification. The material from protected species was collected in compliance with Polish law under permit from the Regional Nature Conservator in Lublin. Research was supported financially by the Ministry of Science and Higher Education of Poland as a part of statutory activities of the Department of Botany, University of Life Sciences in Lublin (project OKB/DS/2) and the Department of Geobotany, Institute of Biology and Biochemistry, Maria Curie-Skłodowska University.

\section{Authors' contributions}

The following declarations about authors' contributions to the research have been made: design of the study: BD, MW; field work: MW, BD, AC; laboratory work: BD; writting the manuscript: $\mathrm{BD}, \mathrm{MW}$.

\section{References}

1. Bascompte J, Jordano P. Plant-animal mutualistic networks: the architecture of biodiversity. Ann Rev Ecol Syst. 2007;38(1):567-593. http://dx.doi.org/10.1146/annurev.ecolsys.38.091206.095818

2. Potts SG, Biesmeijer J, Kremen C, Neumann P, Schweiger O, towards increased self-fertility in order to facilitate reproductive assurance, as shown elsewhere in rare species [51] cannot be excluded. In the flowers of $A$. vernalis, the morphological androecium traits may provide self-pollination. The stamens are inserted in whorls around the style; the long and flexible filaments facilitate anther movement and may allow gravitational transfer of the pollen load onto the stigmas, possibly from proximal anthers, which are the closest to pistils and produce pollen with the highest viability.

Likewise, the functioning of dichogamy depends on how the pollinators act in flowers. The incomplete protogyny may provide pollination if pollinators tend to avoid flowers in the female phase. There is no information about the correlation between floral visits and floral phases for A. vernalis; in this study, we did not monitor insect visitation rates in relation to the floral phases either and thus the implications of our findings cannot be fully evaluated. The preferences of flower visitors for the female or male phase have been documented for different plants, e.g. Geranium sylvaticum L. [52]. The omission of female phase flowers, as non-rewarding, is particularly likely to occur in $A$. vernalis as non-nectariferous floral phases are frequently avoided by different pollinators [53].

Furthermore, the mating system defined on the basis of the pollen/ovule ratio $(\mathrm{P} / \mathrm{O}=501)$ classifies $A$. vernalis as a facultative xenogamous species and may explain the occurrence of spontaneous autogamy as a mechanism for reproductive assurance. According to Cruden [39], the pollen/ovule ratio is a valuable reflection of the breeding system of a plant and indicates the reproductive requirements.

In conclusion, the presence of insect pollinators is necessary for the seed set and reproductive success of $A$. vernalis, although further investigations are necessary to determine the insect visitors effectiveness in pollen transfer. However, in the conditions of the global lack of pollinators, poor pollination may weaken the population by leading to a decrease in the proportion of recombinants, and in addition to other factors, may accelerate extinction of small $A$. vernalis populations.

Kunin WE. Global pollinator declines: trends, impacts and drivers. Trends Ecol Evol. 2010;25(6):345-353. http://dx.doi.org/10.1016/j. tree.2010.01.007

3. Zych M, Jakubiec A. Pollination of Polish red list plants: a preliminary statistical survey. Acta Agrobot. 2008;61(1):85. http://dx.doi. org/10.5586/aa.2008.011

4. Schemske DW, Husband BC, Ruckelshaus MH, Goodwillie C, Parker IM, Bishop JG. Evaluating approaches to the conservation of rare and endangered plants. Ecology. 1994;75(3):584. http://dx.doi. org/10.2307/1941718

5. Zych M, Stpiczyńska M. Neither protogynous nor obligatory outcrossed: pollination biology and breeding system of the european red list Fritillaria meleagris L. (Liliaceae). Plant Biol Stuttg. 2012;14(2):285294. http://dx.doi.org/10.1111/j.1438-8677.2011.00510.x

6. Zając A, Zając M. Elementy geograficzne rodzimej flory Polski. Cracow: Jagiellonian University; 2009.

7. Davis SD, Heywood VH, Hamilton AC, editors. Centres of plant diversity. A guide and strategy for their conservation 1. Europe, Africa, Southwest Asia and the Middle East. Cambrige: International Union for Conservation of Nature; 1994.

8. Schnittler M, Günther KF. Central European vascular plants requiring 
priority conservation measures - an analysis from national red lists and distribution maps. Biodivers Conserv. 1999;8(7):891-925. http:// dx.doi.org/10.1023/A:1008828704456

9. Denisow B, Wrzesień M, Cwener A. The estimation of Adonis vernalis populations in chosen patches of Lublin Upland. Acta Agrobot. 2008;61(1):3. http://dx.doi.org/10.5586/aa.2008.001

10. Cwener A. Threatened xerothermic vascular plants in the Działy Grabowieckie mesoregion (Wyżyna Lubelska Upland, SE Poland). In: Mirek Z, Nikel A, editors. Rare, relict and endangered plants and fungi in Poland. Cracow: W. Szafer Institute of Botany, Polish Academy of Sciences; 2009. p. 155-162.

11. Bilz M, Kell SP, Maxted N, Lansdown RV. European red List of vascular plants. Luxembourg: Publications Office of the European Union; 2011.

12. Korotchenko I, Peregrym M. Ukrainian steppes in the past, at present and in the future. In: Werger MJ, van Staalduinen MA, editors. Eurasian steppes. Ecological problems and livelihoods in a changing world. Plant and vegetation. Dordrecht: Springer Netherlands; 2012. p. 173-196. (vol 6). http://dx.doi.org/10.1007/978-94-007-3886-7_5

13. Meusel H, Jäger E, Weinert F. Vergleichende Chorologie der Zentraleropäischen Flora. Jena: Gustav Fischer Verlag; 1965. (vol 3).

14. Forycka A, Szczyglewska D, Buchwald W. Stock-talking of Adonis vernalis $\mathrm{L}$. in the selected localities in Poland. Bull Bot Gard Mus Collect. 2004;13:55-58.

15. Sudnik-Wójcikowska B, Moysiyenko II, Slim PA. Dynamics of the flora of windbreaks in the agricultural landscape of steppes in southern Ukraine. Biodiv Res Conserv. 2006;1-2:77-81.

16. Parnikoza I, Vasiluk A. Ukrainian steppes: current state and perspectives for protection. Ann UMCS Biol. 2011;66(1). http://dx.doi. org/10.2478/v10067-011-0018-0

17. Świerczyńska S. Problemy zachowania zbiorowisk stepowych na podstawie badań prowadzonych na Lubelszczyźnie. Prądnik: Ojcowski Park Narodowy. Muzeum im. prof. Władysława Szafera; 1990. (vol 2).

18. Michalik S, Zarzycki K. Management of xerothermic grasslands in Poland: botanical approach. Colloq Phytosociol 1995;24:881-895.

19. Mihalik E, Gocs K, Kálmán K, Medvegy A. Reproductive success of the individuals with different age in a planted Adonis vernalis L. population. Acta Biol Debr Oecol Hung. 2000;11(1):270-275.

20. Harper JL. Biologia populacyjna i ekologia organizmów klonalnych. Moduły i rozgałęzienia a pobieranie składników pokarmowych. Wiad Ekol. 1986;32(4):327-359.

21. Falińska K. Plant population biology and vegetation processes. Cracow: W. Szafer Institute of Botany, Polish Academy of Sciences; 1998.

22. Czarnecka B. Spatiotemporal patterns of genets and ramets in a population of clonal perennial Senecio rivularis: plant features and habitat effects. Ann Bot Fenn. 2008;45(1):19-32. http://dx.doi. org/10.5735/085.045.0103

23. Charlesworth D, Charlesworth B. Inbreeding depression and its evolutionary consequences. Ann Rev Ecol Syst. 1987;18(1):237-268. http://dx.doi.org/10.1146/annurev.es.18.110187.001321

24. Lloyd DG, Webb CJ. The avoidance of interference between the presentation of pollen and stigmas in angiosperms. I. Dichogamy. N Z J Bot. 1986;24(1):135-162. http://dx.doi.org/10.1080/00288 25X.1986.10409725

25. Lloyd DG, Schoen DJ. Self- and cross-fertilization in plants. I. Functional dimensions. Int J Plant Sci. 1992;153(3):358. http://dx.doi. org/10.1086/297040

26. Sanzol J, Herrero M. The "effective pollination period" in fruit trees. Sci Hortic. 2001;90(1-2):1-17. http://dx.doi.org/10.1016/ S0304-4238(00)00252-1

27. Douglas KL, Cruden RW. The reproductive biology of Anemone canadensis (Ranunculaceae): breeding system and facilitation of sexual selection. Am J Bot. 1994;81(3):314. http://dx.doi.org/10.2307/2445458

28. Griffin SR, Mavraganis K, Eckert CG. Experimental analysis of protogyny in Aquilegia canadensis (Ranunculaceae). Am J Bot. 2000;87(9):1246. http://dx.doi.org/10.2307/2656717

29. Dafni A, Firmage D. Pollen viability and longevity: Practical, ecological and evolutionary implications. Plant Syst Evol. 2000;222(1-4):113-132. http://dx.doi.org/10.1007/BF00984098
30. Larson BMH, Barrett SCH. A comparative analysis of pollen limitation in flowering plants. Biol J Linn Soc. 2000;69(4):503-520. http:// dx.doi.org/10.1006/bijl.1999.0372

31. Aizen MA, Harder LD. Expanding the limits of the pollen limitation concept: effects of pollen quantity and quality. Ecology. 2007;88(2):271-281. http://dx.doi.org/10.1890/06-1017

32. Denisow B, Wrzesień M. The study of blooming and pollen efficiency of Adonis vernalis L. in xerothermic plant communities. J Apic Sci. 2006;50(1):25-32.

33. Matuszkiewicz W. Przewodnik do oznaczania zbiorowisk roślinnych Polski. Warsaw: Polish Scientific Publishers PWN; 2001.

34. Jankowska-Błaszczuk M. Diagnostyczne właściwości struktury przestrzennej populacji Adonis vernalis L. In: Faliński J, editor. Dynamika roślinności i populacji roślinnych. Warsaw: Białowieża Geobotanical Station of Warsaw University; 1991. p. 193-200.

35. Jankowska-Błaszczuk M. Biologia populacji miłka wiosennego Adonis vernalis L. w rezerwacie "Skowronno". Ochr Przyr. 1995;52:47-58.

36. Medvegy A, Szőllősi R, Mihalik E. Temporal floral sex allocation in protogynous Adonis vernalis L. In: Proceedings of the 2nd European Congress of Conservation Biology. Prague: Czech University of Life Sciences, Faculty of Environmental Sciences; 2009. p. 148.

37. Chmura D, Adamski P, Denisiuk Z. Spatiotemporal aspects of the occurrence of clonal steppe plant Adonis vernalis L. in the southern Poland. Cas Slez Semskeho Muzea A. 2012;61(3):245-250. http:// dx.doi.org/http://dx.doi.org/10.2478/v10210-012-0025-Z

38. Dafni A, Maués MM. A rapid and simple procedure to determine stigma receptivity. Sex Plant Reprod. 1998;11(3):177-180. http:// dx.doi.org/10.1007/s004970050138

39. Cruden RW. Pollen-ovule ratios: a conservative indicator of breeding systems in flowering plants. Evolution. 1977;31(1):32. http://dx.doi. org/10.2307/2407542

40. Gostin IN. Scanning electron microscopy investigations regarding Adonis vernalis L. flower morphology. Analele Univ Din Oradea Fasc Biol. 2009;16(2):80-84.

41. Stanisz A. Przystępny kurs statystyki z zastosowaniem Statistica na przykładach z medycyny. Cracow: Statsoft Polska; 2007.

42. Knuth P. Handbuch der Blütenbiologie. Leipzig: Verlag von Wilhelm Engelman; 1898. (vol 2).

43. Kudo G. Ecological significance of flower heliotropism in the spring ephemeral Adonis ramosa (Ranunculaceae). Oikos. 1995;72(1):14. http://dx.doi.org/10.2307/3546032

44. Chmura D, Adamski P, Denisiuk Z. How do plant communities and flower visitors relate? A case study of semi-natural xerothermic grasslands. Acta Soc Bot Pol. 2013;82(2):99. http://dx.doi.org/10.5586/ asbp.2013.015

45. Goulson D. Foraging strategies of insects for gathering nectar and pollen, and implications for plant ecology and evolution. Perspect Plant Ecol Evol Syst. 1999;2(2):185-209. http://dx.doi. org/10.1078/1433-8319-00070

46. Heinrich B, Raven PH. Energetics and pollination ecology. Science. 1972;176(4035):597-602. http://dx.doi.org/10.1126/ science.176.4035.597

47. Chittka L, Thomson JD, Waser NM. Flower constancy, insect psychology, and plant evolution. Naturwissenschaften. 1999;86(8):361-377. http://dx.doi.org/10.1007/s001140050636

48. Young LW, Wilen RW, Bonham-Smith PC. High temperature stress of Brassica napus during flowering reduces micro- and megagametophyte fertility, induces fruit abortion, and disrupts seed production. J Exp Bot. 2004;55(396):485-495. http://dx.doi.org/10.1093/jxb/erh038

49. Gusta LV, O'Connor BJ, Bhatty RS. Flax (Linum usitatissimum L.) responses to chilling and heat stress on flowering and seed yield. Can J Plant Sci. 1997;77(1):97-99. http://dx.doi.org/10.4141/P95-205 
50. Rodkiewicz B, Śnieżko R, Fryk B, Niewęgłowska B, Tchórzewska D. Embriologia "Angiospermae" rozwojowa i eksperymentalna. Lublin: Maria Curie-Skłodowska University Press; 1996.

51. Steffan-Dewenter I, Tscharntke T. Effects of habitat isolation on pollinator communities and seed set. Oecologia. 1999;121(3):432-440. http://dx.doi.org/10.1007/s004420050949
52. Asikainen E, Mutikainen P. Preferences of pollinators and herbivores in gynodioecious Geranium sylvaticum. Ann Bot. 2005;95(5):879-886. http://dx.doi.org/10.1093/aob/mci094

53. Klinkhamer PGL, de Jong TJ, Linnebank LA. Small-scale spatial patterns determine ecological relationships: an experimental example using nectar production rates. Ecol Lett. 2001;4(6):559-567. http:// dx.doi.org/10.1046/j.1461-0248.2001.00267.x 